\title{
World's largest bioscience fund takes shape
}

In April, the venture capital firm Merlin Ventures (London) merged with part of the Rothschild Bioscience Unit (RBU; London), the biotechnology investment wing of Rothschild bank. The resulting "Merlin Bioscience" (London) will manage RBU's International Biotechnology Trust (IBT; London), which has

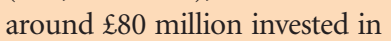
mid-stage biotechnology firms, and Merlin's portfolio of biotechnology company investments. It will also absorb the bulk of RBU's investment and business development specialists, giving Merlin Bioscience

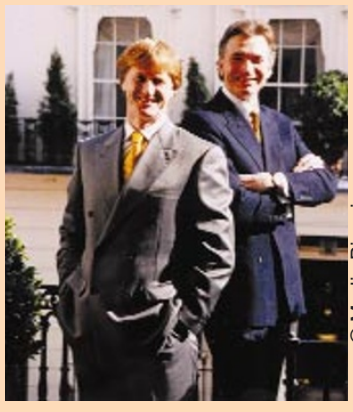

Evans (left) and Jeremy Curnock-Cook, CEO of Merlin Bioscience.

in the sector says Chris Evans, chair of Merlin Bioscience. He says investments up to $£ 12$ million will be made in European mid-stage companies involved in drug discovery, medical devices, and diagnostics. Through European consolidation, Merlin's strategy is to produce 10 or so large firms with a broad range of technology, intellectual property, and business expertise. Evans believes this is the only way to attract large public investments. "What the stock markets are looking for are $£ 200$ million companies," says Evans. over 20 such personnel, the world's largest group of its kind. Merlin Bioscience already has $\mathfrak{£} 150$ million (US\$240 million) invested, and a further $£ 100$ million will be raised by fall this year. "[In total, this] must be approaching one of the largest financial groups" investing

\section{Hepatitis $\mathbf{C}$ collaboration}

On March 23, Ribozyme Pharmaceuticals (Boulder, CO) and Eli Lilly (Indianapolis, IN) agreed to develop a ribozyme therapeutic to treat hepatitis $\mathrm{C}$ virus (HCV) infection. Ribozyme could receive $\$ 38$ million in the form of $\$ 9.2$ million for initial research costs, an equity investment, and payment resulting from Lilly's worldwide commercialization rights to resulting products. $\mathrm{HCV}$, an RNA virus that can lead to liver cirrhosis, cancer, liver failure, and death, mutates rapidly, making it a great challenge to develop a drug for treatment, according to Ribozyme CEO Ralph Christofferson. The Ribozyme/Lilly therapeutic is based on Heptazyme, a ribozyme that targets and cleaves the internal ribosome entry site, a region of the virus' RNA that is common to all mutated strains of the virus and is therefore an excellent target. Viral replication is stopped regardless of how the virus mutates, says Christofferson, and should be disrupted without inhibiting other normal functions. Moreover, the virus replicates in the cytoplasm rather than integrating into the genome; destroying HCV RNA by Heptazyme could allow efficient cellular elimination of the virus. Heptazyme is expected to enter the clinic by the end of the year.

Business and Regulatory News Briefs written by Vicki Brower, Stephen Cass, Jeffrey L. Fox, Adam Michael, and Asako Saegusa.
The deal comes less than two weeks after Rothschild announced it was dropping RBU because of the failed merger of IBT and Biotechnology Investments Limited (BIL; London), also managed by RBU (Nature Biotechnol. 17, 8).

\section{Life's tough for small firms}

US biotechnology companies have seen a $17 \%$ increase in sales to $\$ 13.4$ billion, a $16 \%$ increase in revenues to $\$ 18.6$ billion, and 9\% increase in employees to 153,000 in 1998, according to Ernst \& Young's (Palo Alto, CA) 13th Biotechnology Industry Annual Biotechnology drug approvals have steadily increased over the past few years, with more than 20 drugs either approved or recommended for approval in 1998. And there are more than 300 drugs currently in phase II/III and phase III trials, nearly double the up and biotechnology stock indices have lagged behind other industrial sectors. "There's so much interest in the software and internet sector right now...that's where the money is flowing," says John Taggert, partner at Ernst \& Young Life Sciences. Additionally, consolidation in the financial industry has resulted in larger investment funds, and many smaller companies do not warrant investments. Approximately 250 biotechnology companies have market capitalizations less than $\$ 250$ million, and difficult times are predicted for these. "Either the market will sway and there'll be more interest in small-cap stocks or else there'll continue to be more and more consolidation and shakeouts in the sector," says Scott Morrison, coauthor of the report. Report titled "Bridging the Gap." 1997 figure. Yet public financing has dried

\section{Apax funds Japan biotech}

With a view to rescuing the ailing domestic venture capital market in Japan, Apax Partners (London), the international venture capital group, set up its first Japanese fund in March with Japanese investment group Globis Corporation (Tokyo). The new venture, named Apax Globis Partners, plans to raise US $\$ 150$ million to invest in five key areas of business-IT, telecommunications, media, biotechnology, and specialty retailand is likely to become the largest foreign venture capital fund in Japan. Of the \$30 million invested in biotechnology-related ventures (particularly drug development), $¥ 0.3-0.5$ billion (US\$ $2.4-4$ million) will be allocated to early-stage companies, and $¥ 1$ billion to larger buyouts of undervalued companies.

The Japanese venture capital market has been dominated by affiliates of major commercial banks, although several overseas venture capitalists, such as Schroder Ventures (London) and 3i (London), also occupy a substantial stake in the market. Since the peak of the economic crisis in 1995, Japanese financial institutions have been cutting back loan and investments to venture businesses. However, Apax's move comes in the wake of the government's increased support for start-ups and ventures (Nature Biotechnol. 17, 320-321, 1999).

\section{British Biotech fails again}

At the end of March, British Biotech (Oxford, UK) axed its pancreatitis drug Zacutex after it failed to produce statistical significance in phase III clinical trials. It was this trial that was prematurely unblinded in 1998 by the former head of R\&D at the firm, Andrew Millar, who claimed that the drug did not work (Nature Biotechnol. 16, 609, 1998). As a result of dropping Zacutex (and 60 members of staff), British Biotech says it will save $\mathfrak{£} 10$ million by mid2000. However, press reports have suggested that $\mathfrak{E} 50$ million would have been saved if the company had taken this action during the original furor. Nevertheless, the money saved will go to fund the firm's sole remaining technology focus, metalloenzymes, including matrix metalloproteinase inhibitor BB-3644 for the treatment of various cancers. According to British Biotech, BB3644 produces fewer musculoskeletal side effects than marimastat, the company's lead drug. British Biotech shares are currently trading a sliver above the firm's cash value

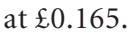

